\title{
The Impact Of Constitution Court Decision About The Abolition Of RSBI/SBI Program Case Study on ex.SDBI No.26 Argamakmur, North Bengkulu Regency
}

\author{
Yuni Indah Supriyanti \\ Universitas Ratu Samban Bengkulu Utara \\ yuniindah356@gmail.com
}

\begin{abstract}
The need of education which is properly accommodated in Constitution Number 20 of 2003 about national education System on article 50, verse 3 which mandate that Government and/or Local Government hold at least one educational unit on whole educational level to be developed as school at international level. After 8 year implementation, through Constitution Court session on Tuesday, January 8, 2013, issued a policy about abolition of international based school. Constitution Court has accepted the complaint which is submitted by Coalition against Commercialization of Education. In its consideration, Constitution Court considers that international school in governmental school is on the contrary to UUD 1945. The purpose of this research is to know about the impact of Constitution Court decision (The Abolition of RSBI/SBI Program) in schools and public institutions in this case about student guardian. This research is also expected to be able to give contribution for knowledge and science especially to research policy in education. The method of this research is qualitative research and case study. This research is held in SDN 26 Argamakmur which is one of Pioneering International School (RSBI). This research uses some informants; they are teachers and administration staffs of SDN 26 Argamakmur, student guardians, the officials of education and culture department of North Bengkulu regency and the officials of education and culture department of regional offices and also some policy experts in the field of education. This research finds out some facts that Constitution Court decision about the revocation of RSBI in SD BI 26 Argamakmur causes the result of psychology pressure for teachers as the spearhead of policy implementer. Before this decision published, the teachers who teach in this school have their own pride to teach in this school. Physically, RSBI School in Argamakmur has some facilities such as computer laboratory, Language laboratory, and ICT room. These facilities need high maintenance fund. Therefore, regional government still has responsibilities toward the impact of status alteration of this school. The alteration of status from RSBI school to regular school results on various impact for society especially students guardian. For the parents who have sent their children to RSBI School, there is a pride form the parents toward their children because they have basic skills that aren't given in other schools. The skills are active English skill and computer skill. Many parents who have their children study in International Standard Primary School (SD BI) feel disappointed since there won't be written international standard school in their children's educational certificate. International predicate is considered as a pride for some parents. The steps taken by school have been based on circular letter of education and culture Minister of Indonesia dated January 30, 2013. That circular letter contents RSBI transition policy.
\end{abstract}

Keywords: Impact, Constitution Court decision, RSBI program. 
2 | TADBIR : Jurnal Studi Manajemen Pendidikan, Vol. 1, No. 01, 2017

\section{Preface}

\section{Background}

Educating the life of nation has been national purpose of Indonesia which is listed in constitution. Furthermore that national purpose is also elaborated in article 31 of Law number 20 of 2013 about National Educational System. Then, to guarantee the execution of qualified education which is based on National education standard has been established in Government Regulations number 19 of 2005 about National Standard of education. Moreover, Law number 17 of 2007 about The Plan of National Long-term Development. National education department assigns scale stage of priority in $1^{\text {st }}$ medium-term development plan in 2005-2009 to increase quality and society access toward educational service. The need of qualified school increases along with the increase of society education level.

The need of proper and qualified education is craved by society, therefore in Law number 20 of 2003 about national education system in Article 50 verse (3) stated that Government and/or Local Government hold at least one educational unit in each education level to be developed as international standard school.

International standard school is a school which has completed National standard of education and enriched by referring to education standard of one member states of Organization for Economic Cooperation and Development (OECD) and/or another developed country which has specific superiority in education so it has competitiveness in international 
forum. The purpose of developing international standard school is in order to the students are able to compete in globalization era, familiarize themselves to use English in daily conversations and ease the student to continue their education to abroad.

The program of International Standard Primary school is started in 2004. There are 22 RSBI school (Pioneering International School) and several regular schools which have national standard are set to be International standard school. North Bengkulu regency is one of the regencies which achieve the program. According to the data from solo.com, there are about 1.035 schools which consist of Primary School, Junior High School, senior High School/Vocational School are expected to be international standard school.

After 8 year implementing, through Constitution Court session on Tuesday, January 8, 2013, government published abolition policy of international standard school. Constitution Court has granted the lawsuit filed by a coalition of anti Commercialization of Education. In its consideration, Constitution court assumed that international standard school in governmental school contradicted with UUD 1945. RSBI school causes dualism of education, expensiveness of cost causes some discrimination in education, differentiation of RSBI/SBI school and non RSBI/SBI school caused caste in education. The court said that the government should be able to give special treatment for those who have special skills; nevertheless giving different service can not be in the form of RSBI/SBI school and non RSBI/SBI school. It is because this case shows that there is 
different treatment from government, as facility, fund rising, infrastructures. The implication of differentiation caused only the RSBI/SBI school which enjoys the adequate facilities. Whereas non RSBI/SBI school get limited facilities, as said by the judge while reading the decision.

This decision removed basic law of governmental school with international label. For the government (Education and Culture Ministry), there is no choice except obey and appreciate the decision of Constitution Court, as the institution that conduct judicial review toward law which is assessed contradicted to UUD 1945.

The beginning of 2007, SD N 26 Argamakmur became one of RSBIschool which was established by the government and became the program of National Education Department. For 6 years, SD BI Argamakmur has conducted an action pattern which approached international standard school. As for behavior patterns which formed were: both students and teachers were accustomed to greeting in English, the students were accustomed to full daily routines. Management program which is conducted by SDN 26 Argamakmur is $100 \%$ directed to development standard of international school. It was proved by academic achievement of the school, for example achieving Grade A (94).

According to those background problems, the researcher conducted the research toward the impact of Constitution Court decision to the school and society. 


\subsection{Problem Formulation}

1. How is the impact of constitution court decision about RSBI/SBI toward ex. SD BI and society?

2. What are the steps conducted by the school to address the transition period of school status post the decision of constitution court?

\section{Literature Review}

\subsection{The Impact of Program}

The discussion about the program is related to policy aspect. According to Dye, the policy which in this occasion is about public policy, principally can be defined as "whatever government choose to do or not to do". Parsons (2006:17) said that policy is commonly used to show important choose taken in organization's or private life.

According to Jones, the word "Policy" is often used to refer to the purpose of the program, decisio0n, law, proposal, standard and certain major intent.

The same opinion with Jones is stated by Laswell and Kaplan (in Islamy 2009:15) that policy is a program to reach the purpose, values and directed practices. Suharto (2006:7) said that the term of policy is form English word which is differentiated to wisdom or virtue.

Based on those opinions, it can be concluded that public policy is oriented to behavior or decision making by state officials to solve the problem with some alternative ways. Public policy is the 
decision made by state institution in order to reach vision and mission of a nation.

Whereas the definition of program, according to Jones, program is a legal way to reach the purpose. In that definition, it is elaborate that programs are elaboration of steps to reach the purpose itself. In this case, government program means the effort to actualize the government's policies. The program appears in the Strategic Plan of Ministry or Government Work Plan.

All the policies certainly generate the impact, both positive and negative impacts. The positive impact is defined as the impact which expected to happen as the result of policy and give benefit to the environment of the policy. Whereas the negative impact is defined as the impact this doesn't give any benefit for policy environment and isn't expected to be happened.

Soemarwoto in Giroth (2004) stated that the impact is an alteration which happens as the result of an activity. The alteration is looked in the goals of policy. Policy goal can be society or institution.

\subsection{RSBI School (Pioneering International School)}

According to Widyastono, SD/M BI which is a primary school with international standard is a kind of school that:

1. Has fulfilled the national standard of education

2. Is enriched with referring to education standard of one of OECD (Organization of Economic Co-Operation Development) countries and other developed countries which have specific 
privilege in Education aspect so that have competiveness in international forum.

Formal legal of RSBI policy is Law Number 20 of 2003 about National education system in article 50 verse 3, stated that: The Government and/or regional government hold at least one education unit in each education level to be developed to be international standard school.

Then, verse 3 article 50 Law number 30 of 2013 is derived in Permendiknas Number 78 of 2009.

\subsection{Constitution Court}

Constitution court is one of the subjects of judicial power as intended in UUD 1945 of Indonesia. While, the role of Constitution court is essential in harmonizing the relationship among the state institutions which often collide each other. The judge of constitution court must be completed with expert group which functionate to give insight and judgment for constitution court to guarantee the accountability of its decision.

\section{Research Methodology}

This research uses qualitative description design, case study on ex. SDBI Argamakmur. The technique of deciding the informant is through snowballing sampling and key persons. Data collection method used in this research is interview method. The result of this research will be analyzed by using qualitative descriptive analysis method. The step of data analysis of this research is Interactive Model analysis by Miles and Huberman. The writer used triangulation method for data validity need. 


\section{Discussion}

\subsection{The Impact of MK decision (Constitution Court Decision)}

Soemarmoto in Giroth (2004) stated that impact is a alteration happened as the result of an activity. The alteration looks in the target of policy. The target of the policy is society or institution. In this case, it will be discussed the alteration on the target of RSBI program which are School and Society.

There were many pro and contras about the background of releasing this decision when this decision was declared at first. Most of them asked about the background of releasing Law Number 20 of 2003 article 50 verse 3 which is expanded to be international standard school by National Education Minister. The decision affects so much for the schools and society.

1. The Impact for schools:

a. Psychology Impact

The decision of Constitution Court about the revocation of RSBI causes psychology pressure for teachers as the spearhead as the implementer of the policy. Before the decision released, the teachers of RSBI have their own pride to teach in RSBI School. It is stated by Ind:

"Ya, certainly we were recruited strictly. So, being graduated and placed in SD BI is a big pride for us."

CNI also has the same perception with Ind. She stated that at the first time of SBI in Argamakmur, she felt pride. All activities were centered in SD BI. When there were some events or championships, the students of SDBI would be chosen first to be the representative or North Bengkulu regency. Ind also said that 
deleting RSBI status and her school became regular school could cause anxiety about the status of honorary teachers who were recruited in 2007.

Rst stated that she felt worry that the salary of honorary teachers would not be budgeted in APBD. Then, CNI also said that besides the status about honorary teachers, she felt worry about employment status as teachers after no longer using the program of SBI. Hn stated that the alteration of status form RSBI to be regular school would affect the amount of teaching hours. It meant that not all teachers would get 24 hours per week considered the big number of teachers and the less of learning hours.

Then Mst defined that regular status of primary school caused reducing of 10 hours/week of English. It was meant that the English teachers have the lack of teaching hours and as the result those teachers could not get functional allowance as non PNS teacher.

Based in the opinion of the informants, it can be concluded that psychology pressure felt by honorary teachers are also felt by PNS teacher. The worries are responded by Education and culture Department through the head of official department, Ibr. Ibr stated that Education and Culture Department of North Bengkulu will still propose the salary of honorary teachers in APBD of regency government of North Bengkulu.

The policy of education and culture department of North Bengkulu, for PNS teacher who teach in SDBI will get operational incentive allowance. It also causes prestige because 
the allowance is only given to PNS teachers who teach in SD BI schools.

The alteration of SDBI status to regular school affects to the amount of teaching hours of the teachers, especially English teachers. In RSBI period, English hour was 10 hours per learning class but after the decision of the alteration of RSBI, English teaching hour was only 2 hours for each learning class (It is related to the system of DAPODIK). This condition caused pressure on English teacher. It was stated by Hni. Hni said that how they could feel comfortable in teaching English if the hour of teaching was decreased, certainly they didn't get Functional Allowance.

Psychology pressure is worsened with the conflict among PNS teacher and non PNS teachers. The conflict is sparked by nominal budget estimation of overtime payment among PNS teachers and non PNS teachers which is different significantly. Although the conflict has been reconciled by the government of North Bengkulu through Education and Culture Department, the conflict still caused the cold war among the teachers and at last it caused bad effect to teaching and learning activity at school.

b. Physical Impact

RSBI School in Argamakmur has some facilities such as computer laboratory, language laboratory, ICT room. Those facilities certainly need large amount of maintenance fund. This case is clarified by the headmaster of SD BI Argamakmur, Snrm. Besides, Snrm also stated that operational fund of SD BI is quite large especially for electricity and water. If there's no budgeting 
support from the regional government, the school can't maintain the school operational activity.
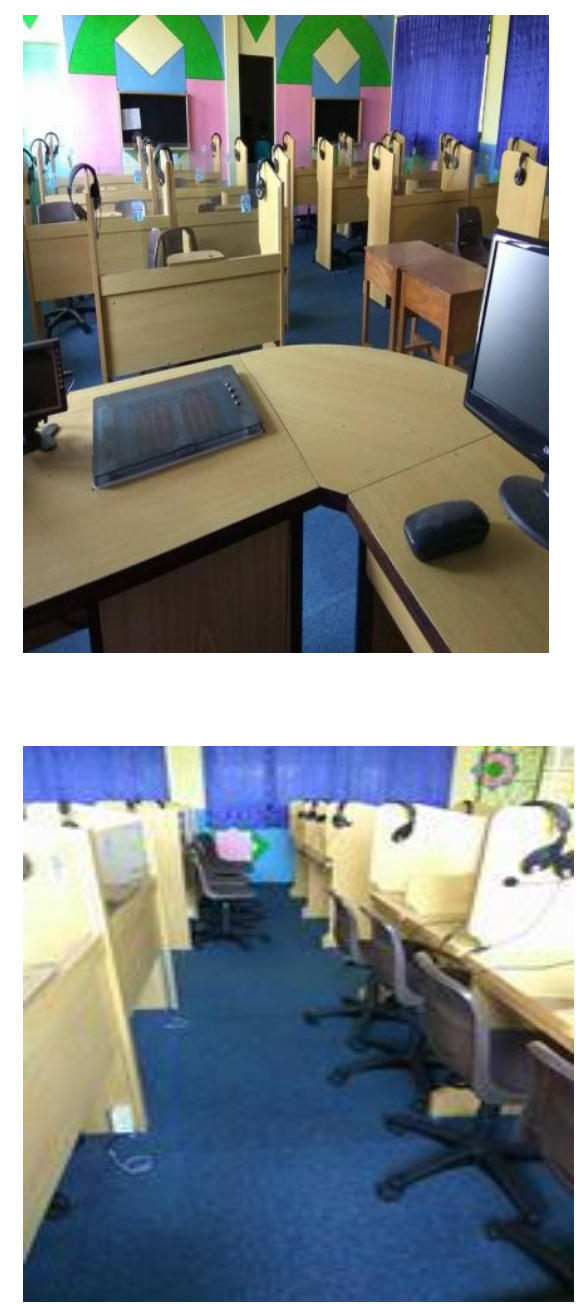


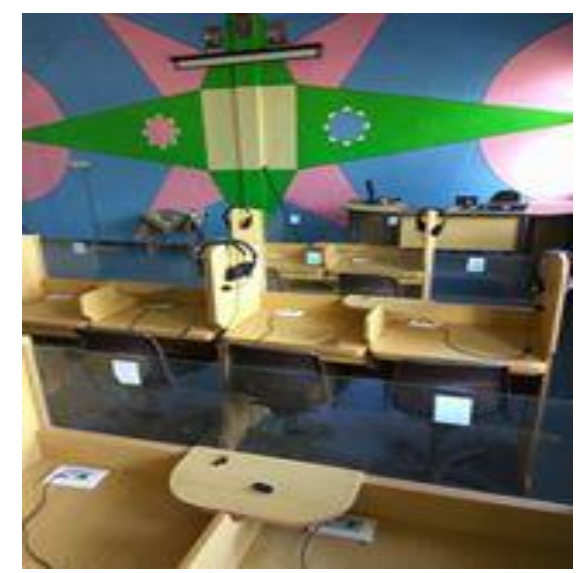

Dokumentation of SD N 17 Argamakmur 2017

The Picture shows recent condition of computer laboratory which is never used anymore. The information is given by one of recent SD BI teachers which this school have became SD N 17 Argamakmur. According to this teacher now there isn't English subject and the laboratory is rarely used. The curriculum used is 2013 curriculum. According to the head of LPMP, Sa'dahRidwan in the opening of 2013 curriculum training, she stated that 2013 curriculum is the improvement of previous curriculum. She said that if we liken curriculum as clothes, 2013 curriculum is an ideal cloth which both sleeves and legs have the same size. So, 2013 curriculum is the improvement of previous curriculum. C2013 curriculum is different to previous curriculum implemented by the primary school. In the precious curriculum it was stated that English subject is allocated for 10 hours, but now in the implementation of 2013 curriculum there isn't English subject.

The head of financial unit of North Bengkulu Education and Culture Department stated that the department will still 
support the fund for SD BI School which has changed the status to be regular school.

The head of UPTD also stated that the department of education and culture will not be irresponsible to the impact of status alteration of SD BI School.

Based on the opinion above, it can be concluded that the regional government is still responsible to the impact of status alteration of that school.

2. The Impact for Society

The status alteration form RSBI to regular school affects variously in society especially for the student guards. For the parents who have ever sent their children to SDBI, Edw stated that he felt so disappointed with the decision of the abolition of school status. It is because the outputs of SD BI are able to compete with other students in favorite Junior High School. According to Eds's statement, his son can speak English actively and has good computer skill.

As parent, Ev also stated that she has her own pride having children who study in SDBI. She felt happy that his son has the certificate of international standard school.

According to both opinions, it can be concluded that the parents have special pride on their children who have basic skill which other children in regular school don't have, they are active English skill and good computer skill.

For the parents whose children still study in SD BI, some stated that they feel disappointed and some stated that they feel satisfied 
with the decision. Ang said that he felt disappointed because in his son's certificate there isn't any statement about international standard school. The alteration of school status also affects on the alteration of school attributes especially the name of the school. In the first of constitution court's decision, SBI changed to be SD N 26 Argamakmur. In the beginning of 2013/2014 academic year the school changed to be SD N 17 Argamakmur because of the division of district.

While for Wn, she said that she felt satisfied on the decision because she felt burdening with paying monthly school fee. Based on the circular letter of ministry number 017/MPK/SE/2013, it's stated that the school isn't allowed to take charges from the society. The school has to apply school financing management of regular school with school-based management.

The decision on constitution court affects on the pattern of new student recruitment. In 2013/2014 academic year, the school didn't hold new student recruitment. It was stated by $\mathrm{Yn}$ as the head of new student committee. Yn stated that because of regular school status, the school didn't need to hold new student recruitment. All students have the same right to register in the school and also use the facilities of international standard school. Yn also said that the number of this year student is 45 students. It is not different to the previous year. The number of student which doesn't significantly increase is caused by society perception that registering to this school needs large number of fund. 
According to the committee treasurer of SD BI, the school fee during 2007 until this year gradually increases start from Rp 35.000,-, Rp. 50.000,-, and at last Rp. 75.000,-. According to the head of student recruitment, Shl said that the school never charges registration fee and there isn't development fee, there is only the fee for school uniform.

\subsection{The Steps taken by School after Constitution Court's Decision}

Constitution Court is the keeper of constitution and democracy. One of Constitution Court's authority as regulated in chapter 10 verse 1 of Law number 24 of 2003 about Constitution Court as it is changed by Law number 8 of 2011 about the change of Law number 24 of 2003 about Constitution Court which is read:

"Constitution Court has authority to judge at the first and the last level which its decision tends to be final for:

1. Testing the law toward UUD 1945 of Indonesia

2. Deciding authority dispute of state institutions whose authority is given by UUD 1945 of Indonesia

3. Deciding dissolution of politic parties

4. Deciding the conflict about general election result

The decision of Constitution Court achieves directly permanent law power since it is stated and there isn't any legal effort that can be taken. Final tend of Constitution Court decision in this law also consists of a banding legal force (Final and binding) which is elaborated in Chapter 10 verse 1 of Constitution Court Law. Final means the decision of constitution court has permanent law power after it is stated in the opened council for public and there 
isn't law effort that can be taken toward this decision. Binding feature of Constitution Court decision means that constitution court doesn't only apply for some parties but also all Indonesian societies.

In the interview to the speaker of Constitution Court, dr. HajarLaksono said that the decision of constitution court is the reflection of constitution values and it has to be implemented. No one can avoid this decision. This decision applies for all Indonesian societies.

Responding to the decision of Constitution Court about International School policy, Hajar said that pro and contras are not the authority of constitution court. It is the sociology aspect of constitution court decision. The decision of constitution court is final and binding. It means that after the decision legalized, there's no law effort which can be taken and it is applied for everyone. The decision of constitution court about the abolition of international standard school is final decision and it has to be implemented. Hajar also elaborated that the implementation of constitution court decision is the challenge of every countries included Indonesia. If there's the decision of Constitution Court, then it has to be followed up by the authorized institution. If the decision of Constitution Court is not be implemented, then it becomes law violation.

After the decision of Constitution Court number: 5/PUUIX/2012 dated January $8^{\text {th }}, 2013$ was released, the circular letter of Indonesian Education and Culture Minister dated January $30^{\text {th }}$ 
2013 was also released. The letter contains the policy of RSBI transition. The letter stated 4 things:

1. Institutional

2. Learning and Teaching Process

3. Financing

4. Government Responsibility

The letter contains the statement that all schools which have been given license form the ministry of education and culture as international standard pilot school (RSBI) have became regular school which is guided by province government. All nameplate, letterhead and school stamp which mention RSBI name can not be used in the process of administration. In the relation to the status of school, SD N BI (SekolahDasarNegeri) Argamakmur has changed into SD N 26 Argamakmur. According to the curriculum deputy, Snr, S.Pd.,the school has to change the curriculum. Besides school name, the school has changed the stamp, letterhead and release school nameplate.

In the relation to process standard of learning and teaching activity, in the circular letter it's stated that RSBI still implements activity and budget plan until the end of academic year 2012/2013. To respond on this case, the school held a meeting with students' parents on April 15 2013. The result is that school fee, Rp. 75.000,-, must be paid until July 2013 since school program still has to be continued based on the plan of budgeting in 2012/2013. The fact that the school fee is about Rp. 75.000 ,- shows the difference to RSBI in Java island. 


\section{Conclusion}

The decision of Constitution Court about the abolition of RSBI in SD BI 26 Argamakmur causes psychology pressure for the teachers as the spearhead of this policy. Before the decision is released the teachers of RSBI feel proud to teach in this school. The psychology pressure is getting worse because of the conflict among PNS and non PNS teachers. The conflict is triggered by significant difference of overtime payment nominal among PNS and non PNS teachers. In physic aspect, RSBI School in Argamakmur has some facilities such as computer laboratory, language laboratory and ICT room. The facilities need large number of maintenance. The regional government is still responsible to the impact of school status alteration.

The alteration of RSBI status to regular school affects various respond in society especially for the parents. For the parents who have ever registered the children to the school. There is special pride form the parents who ever register their children to get basic knowledge which other same age students don't gain. The skills are active English and good Computer Skill.

For the parents whose children still study in SDBI, it is so disappointed because there is no written statement of international label in the certificate. International predicate is a pride. In the other hand, there is parents who feel satisfied because they font need to pay the school fee for every month. 
The steps taken by the school has been based on circular letter of Education and Culture of Indonesia dated in January 30 2013. The circular letter consists of 4 things, they are:
a. Institutional
b. Learning and Teaching Process
c. Financing
d. The responsibility of regional government

\section{Bibliography}

Anderson, J.E., 1979. Public Policy Making, New York: Holt, Rinerhart and Winston

BunginBurhan. 2009, PenelitianKualitatif, Komunikasi, Ekonomi, KebijakanPublik, danIlmuSosialLainnya, PT FajarInterpratama Offset, Jakarta

Dunn, N.W. 2000., PengantarAnalisisKebijakanPublik, alihbahasa: SamodraWibawa, Yogyakarta, Gajah Mada University Press

IslamyIrfan M., 2009, Prinsip-PrinsipPerumusanKebijakan Negara, Jakarta, PT BumiAksara

Jenkins, W.I., 1978 Public Analysis, Oxford: Martin Robertson

Jones Charles O, 1991, PengantarKebijakanPublik, Rajawali Press, Jakarta

KebanYeremias, 2004EnamDimensiStrategisAdmistrasiPublik: Konsep, TeoridanIsu,PenerbitGava media, Yogyakarta.

Miles dan Huberman,1984, Interactive Model Analysis, Oxford, England

NugrohoRiant, 2010, Public Policy, DinamikaKebijakananalisiskebijakan-manajemenkebijakan, PT Elex Media Komputindo, Jakarta,

Parson, Wayne, 2006, Public Policy PengantarTeoridanPraktek, AnalisisKebijakan, Kencana Jakarta

Suharto Edi., 2010, AnalisisKebijakanPublik, PanduanPraktisMengkajiMasalabSosial, CV Alpabetha Bandung 
Tilaar, H.A.R danNugrohoRiant., 2008. KebijakanPendidikan, Pengantaruntukmemahamikebijakanpendidikandankebijakanpendidikanse bagaikebijakanpublik. Yogyakarta: PustakaPelajar

Undang-UndangDasarTahun 1945 (amandemen)

$\begin{array}{lllll}\text { Undang-Undang } & \text { No } & 20 & \text { Tahun } & 2003\end{array}$

TentangSistemPendidikanNasional

UU RI No. 24 Tahun 2003 TentangSusunan MK

PP No 19 tahun 2005 Tentang Standar Pendidikan Nasional

Putusan MK Nomor 5/PUU-IX/2012TentangPenghapusan $\mathrm{RSBI} / \mathrm{SBI}$

Rencana strategis Departemen Pendidikan Nasional tahun 20052009

BukuPanduanPenyelenggaraanRintisanSekolahBertarafInternasio nal

http://www.solo.com. Diakses tanggal 5 April 2013

http://www.JPNN.com. Diakses tanggal 5 April 2013

Error! Hyperlink reference not valid.diakses 9 Januari 2013

http://www.pekanbaru.tribunnews.com. Diakses 5 April 2013 